\title{
Indonesian Youth on Social Media: Study on Content Analysis
}

\author{
Daniel Susilo ${ }^{1, a}$ and Teguh Dwi Putranto ${ }^{2, b}$
}

${ }^{1}$ PhD Candidate at Social Sciences Program, Airlangga University, Faculty of Social and Political Sciences, FISIP - C Building, $1^{\text {st }}$ Floor, Dharmawangsa Dalam Surabaya, Surabaya, East Java, Indonesia

${ }^{2}$ MA Candidate at Media and Communication Program, Airlangga University, Faculty of Social and Political Sciences, FISIP - A Building, $2^{\text {nd }}$ Floor, Dharmawangsa Dalam Surabaya, Surabaya, East Java, Indonesia

adaniel-16@fisip.unair.ac.id, ${ }^{b}$ teguh.dwi.putranto-2016@fisip.unair.ac.id

Keywords: Indonesian Youth, Social Media, Content Analysis

Abstract. Indonesia is the biggest of Social Media user on Southeast Asia has been rapidly changing on Social Media Platform. In the earliest of 2010, Facebook has been dominating Indonesian Social Media usage. Since 2012, the trend became turn on to Twitter and Instant messaging. This article would describe how the Indonesian Youth was creating the meaning of Social Media usage. This research used a qualitative approach to explore the depth reason from the Indonesian Youth. Content Analysis used as methods for this research. The researcher used an institutional setting on fifteen subjects of Indonesian youth and create the daily log of conversation about their activity and usage on Whatsapp application during three months since December 2016 February 2017. Collected data analyzed with content analysis model with a focus on how the subject created the meaning of social media and especially on the changes in social media platform.

\section{Introduction}

Today, we are faced with enormous challenges in human life. The challenge is not only in one aspect but affecting many aspects; the challenge is Globalization. Globalization comes from a foreign language (Globalization) is global means universal and prefix of lization means process. So the origin of the word globalization is the process of widening new elements of thought, lifestyle, information and technology with no boundaries limits or worldwide.

Globalization can also be interpreted as a process whereby in everyday life, information and ideas become standard benchmarks around the world. The process is caused by the increasing sophistication of information and communication technology and transportation and economic activities that have entered the global marketplace.

One of the significant changes is the big changes in the world of technology and communications because globalization can be interpreted as a process where the boundaries within a country become narrower because of the ease of interaction between countries whether trading, lifestyle, information or in the form of communication other. So indirectly we are close to someone who is far away from us with the presence of this increasingly sophisticated technology. It has been facilitated all with the presence of the internet that we have long known and the emergence of new social media.

The rising number of Internet users in Indonesia cannot be separated from the development of infrastructure and easy to get a smartphone or handheld device. Another reason is that if only a few vendors and handheld devices, now the number of lots and the price is lower.

Social media has become a new need in human life that has replaced the primary needs. The survey conducted by the Association of Indonesian Internet Network Providers (in Bahasa Indonesia, Asosiasi Penyelenggara Jaringan Internet Indonesia/APJII) [1] revealed that more than half of Indonesia's population has now been connected to the internet. The survey, conducted throughout 2016, found that 132.7 million Indonesians were connected to the internet. As for the total population of Indonesia itself as much as 256.2 million people. This indicates a 51.8 percent increase compared to the number of internet users in 2014 ago. Surveys conducted APJII in 2014 
there are only 88 million Internet users.

Survey data also revealed that the average internet users in Indonesia use handheld devices. The statistics are as follows:

- 67.2 million peoples or 50.7 percent access via handheld devices and computers.

- 63.1 million peoples or 47.6 percent access from smartphones.

- 2.2 million peoples or 1.7 percent access only from computers.

Based on the another survey ComScore, Whatsapp Messenger became the top application for Indonesian People [2]. In this paper, the important thing that will be revealed is how the user WhatsApp in a group interact with each other. How each in a group behaves through a written conversation so that the other individuals in the group interpret each communication that occurs within the WhatsApp group. This article used Content Analysis to analyzed the chat from Indonesian youth on Whatsapp Group.

\section{Data and Reliability Test}

The researcher collects the data based on conversation on Whatsapp Group of Master Student Social Sciences Airlangga. The data gathered during 1 December 2016 - 28 February 2017. Researcher uses the Krippendorff model of content analysis. Krippendorff state Content analysis is the fundamental method based on data generated from human observers' judgment by recording or transcribing the textual, visual, or audible messages in human communication [3].

Reliability test is used to test the truth of data obtained, as well as to determine the level of consistency of data measurement. Reliability test performed by two coders among others: This research uses Holsti [4] formula to calculate data obtained from both coder.

$$
\mathrm{PAo}=2 \mathrm{~A} /(\mathrm{N} 1+\mathrm{N} 2)
$$

where PAo represents a percentage of agreement between two coders, $\mathrm{A}$ is the number of two coders' consensus decisions, and $\mathrm{N} 1$ and $\mathrm{N} 2$ are numbers of decisions coders have made respectively.

\section{Indonesian Youth Characteristic on Whatsapp Group}

Young people in the 20-24 year age range and 25-29 years old have penetration rates of up to 80 percent of internet users in Indonesia [1]. This figure is relatively high compared to other age group population. Based on a recent research released by the Association of Internet Service Providers Indonesia. In the category of 20-24 years found 22.3 million people are equivalent to 82 percent of the total population in the group. While in groups of 25-29 years, there are 24 million internet users or 80 percent of the total number of people.

For the Indonesian youth, social media is not only used as a tool to communicate only. But now the media has been used as a place to share everything, not only what they are doing today but also used as a place to complain. In addition, social media is used as a place to transact goods, where to find a partner even also be a place to show social class in the community.

With the convenience provided by social media, youth should be able to utilize the presence of social media with the maximum possible. Of course we must be aware of the presence of social media in our lives that bring impact, not only positive impacts but also negative impacts. Therefore as a young generation we must be wise and able to distinguish which will have a positive impact rather than negative impact.

During our observation, 78\% of member on Whatsapp Group are active user. User used the group like their real inner-circle group. They share about their daily life activity like lunch and or dinner photo, college life, and personal opinion. $45 \%$ user direct reply on the another user posting with thumb symbol to represent their agreement, or comment about what another user post about daily life. 


\section{Content Analysis of Indonesian Whatsapp Group}

Content analysis is a systematic research method base on quantitative research for examining symbolical content in communication. Content analysis focusing by recording or transcribing these messages into categories [5]. Content Analysis as approach, explain about "the study of recorded human communications" [6]. Krippendorff state about content analysis as the one significant technique in quantitative research and social sciences because it is an unobtrusive technique that enables researchers to examine messages "in view of the meanings, symbolic qualities, and expressive contents” [3] under certain contexts.

During our observation, researcher divided two type of posting and their activity on Whatsapp Group. Researcher analyzed the conversation on Whatsapp (text, image/photo, and video) and classified it in to the matrix.

Table 1.

User Activity Classification during December 2016- February 2017

\begin{tabular}{|l|l|l|l|}
\hline \multicolumn{1}{|c|}{ Subject } & \multicolumn{1}{|c|}{ Age } & \multicolumn{1}{c|}{ Text } & Video and Photo \\
\hline A & 23 & 1201 & 7 \\
\hline B & 23 & 1188 & 1 \\
\hline C & 26 & 167 & 12 \\
\hline D & 24 & 690 & 3 \\
\hline E & 26 & 161 & 5 \\
\hline F & 21 & 1310 & 22 \\
\hline G & 19 & 1330 & 21 \\
\hline H & 20 & 1311 & 30 \\
\hline I & 20 & 1341 & 21 \\
\hline J & 20 & 1321 & 20 \\
\hline K & 21 & 490 & 23 \\
\hline L & 21 & 898 & 5 \\
\hline M & 22 & 876 & 1 \\
\hline N & 21 & 1211 & 4 \\
\hline O & 24 & 445 & 0 \\
\hline
\end{tabular}

Based on this table, researcher found in the range of 19-22 years old, user more talk-active and more active on Video and Photo posting. Researcher found Subject F, G,H,I, J, are the starter of topic. They usually replying the chat with text and emoticon. They are more expressive on their chat especially what they are posting on photo and video.

User on 24+ years shows the trend more calm when using the social media. They also more less on photo and video sharing. User on 24+years became more wisely on reacting of the chat on Whatsapp group.

During our observation, researcher also classified type of posting and their activity on Whatsapp Group. Researcher analyzed the conversation on topic from Whatsapp (text, image/photo, and video) and classified it in to the matrix.

Table 2.

Topic Classification during December 2016- February 2017

\begin{tabular}{|l|l|l|l|}
\hline \multicolumn{1}{|c|}{ Topic } & \multicolumn{1}{|c|}{$\begin{array}{c}\text { December } \\
2016\end{array}$} & January 2017 & \multicolumn{1}{c|}{$\begin{array}{c}\text { February } \\
2017\end{array}$} \\
\hline Friendship & 69 & 40 & 81 \\
\hline Politics & 20 & 231 & 44 \\
\hline Personal Communication (Peer to Peer) & 4412 & 4420 & 4404 \\
\hline Information & 19 & 110 & 90 \\
\hline TOTAL & 4520 & 4962 & 4619 \\
\hline GRAND TOTAL & \multicolumn{3}{|c|}{14101} \\
\hline
\end{tabular}

Based on the table 2, majority of posting dominate by Peer to Peer Personal communication 
inter-user. Youth used social media as personal communication peer to peer even they are in the group of chat. Youth use social media group chat like their real life. They talk each other (peer to peer) and anyone on group who don't have any relations with that chat know what they are chat.

Young people use social media not only for personal communication, but also means to vent. they ignore others in the chat group. This behavior dominates over $90 \%$ of the chat topic.

\section{Conclusion}

Based on the analysis of the data, the researchers concluded that young users of social media use group chat as a means of personal communication (peer to peer). they ignore the context in which group chat is a public area where everyone can access it and interpret the content of the message themselves.

Researchers also found the tendency of increasing age of social media users, the decreasing intensity of conversations within the group chat.

\section{Acknowledgement}

In this paper, the research was sponsored by the Indonesian Endowment Fund for Education, Ministry of Finance, Republic Indonesia.

\section{References}

[1] Asosiasi Penyedia Jasa Internet Indonesia. . Profil Pengguna Internet Indonesia 2014 (Profile of Indonesian Internet User 2016), 2017. APJII. Jakarta. 83-85.

[2] Pratama, Aditya H. Whatsapp adalah Aplikasi Terpopuler di Indonesia. (Whatsapp as The Popular Mobile Application in Indonesia). Tech Asia. April 4, 2017. Retrieved from https://id.techinasia.com/comscore-whatsapp-adalah-aplikasi-terpopuler-di-indonesia, access on September 8, 2017.

[3] Krippendorff, Klaus. Content analysis: An introduction to its methodology. Sage, 2004.20-26.

[4] Holsti, Ole R. "Content analysis for the social sciences and humanities." (1969): 602-611.

[5] Berelson, Bernard. Content Analysis in Communication Research. Free Press, 1952. Content analysis in communication research. 31

[6] Babbie, Earl. The Practice of Social Research (9th Ed.). Belmont, CA US: Wadsworth/Thomson Learning, 2001.102. 